\title{
Kizomba Dance: From Market Success to Controversial National Brand
}

La danse kizomba : du succès commercial à une marque nationale controversée La danza kizomba: de éxito de mercado a marca nacional controvertida

Livia Jiménez Sedano

\section{(2) OpenEdition}

\section{Journals}

Electronic version

URL: https://journals.openedition.org/remi/13584

DOI: $10.4000 /$ remi. 13584

ISSN: $1777-5418$

Publisher

Université de Poitiers

Printed version

Date of publication: 1 December 2019

Number of pages: 107-127

ISBN: 979-10-90426-65-8

ISSN: 0765-0752

\section{Electronic reference}

Livia Jiménez Sedano, "Kizomba Dance: From Market Success to Controversial National Brand", Revue européenne des migrations internationales [Online], vol. 35 - n³ et 4 | 2019, Online since 01 January 2022, connection on 14 April 2022. URL: http://journals.openedition.org/remi/13584 ; DOI: https:// doi.org/10.4000/remi. 13584 


\section{Kizomba Dance: From Market Success to Controversial National Brand}

\section{Livia Jiménez Sedano}

\section{Introduction: The Kizomba Battlefield in Context}

The couple dance popularly known as kizomba became fashionable in the 1980 s in the Portuguese-speaking "African"2 communities living in Africa and Europe sharing transnational ties. It was danced to zouk music from the West Indies (Guilbault, 1993) and derived from musical styles produced by artists from the PALOPs ${ }^{3}$ (Cidra, 2010a) that entered into popularity in that period. Musical hits developed by artists from the French Antilles, produced in Paris and labelled as zouk became a great success from the 1980s onwards in France, parts of West Africa, America, Asia and certain cities in Europe through transnational connections. By the 1990s, the most emblematic Antillean zouk band, Kassav, was touring Portuguese-speaking Africa and fostering the already existing passion for their music in that region.

In each context, people danced in many different ways in keeping with the influence of local styles, such as the popular semba dance in Angola (Moorman, 2008) or coladera in Cape Verde (Cidra, 2011). Even though the myth of origins held by most dance school teachers in Europe generally points to Angola as its original source, the dance derives from the result of deep transoceanic, interAfrican and transnational connections (Jiménez, 2020). In the 1990s, it was commodified in Portugal and attained great success in dance schools and clubs, shrinking the hitherto wide variety of existing dancing styles into a pack of "basic steps". In less than one decade, it became a global phenomenon following in the footsteps of the transnational salsa circuits of teachers and festivals, spreading not only through Europe and the USA but also through Eastern Europe, Asia, as well as North and West Africa (Kabir, 2014; Soares, 2015; Jiménez, 2019).

\footnotetext{
1 Department of Social and Cultural Anthropology, UNED (National Distance Education University), Faculty of Philosophy, Paseo Senda del Rey 7, 28040 Madrid, Spain; liviajs@fsof.uned.es

I wish to thank Professor Jocelyn Guilbault for her insightful comments on a previous version of this paper.

2 Ethnic and ethno-national categories are here considered objects of analysis and not scientific categories (Brubaker, 2002; Wimmer, 2013; Díaz de Rada, 2014). For such reason, they appear in quotation marks.

3 PALOPs is a Portuguese acronym standing for those African countries with Portuguese as their official language.
} 
This paper's objective involves analysing how the successful globalization of a dance style - kizomba - impacted on the symbolic representation of a nation - Angola - in a neoliberal context in which nations have turned into competitive brands in the global economy (Comaroff and Comaroff, 2009). The key argument is that global market forces have become especially powerful and capable of defining national symbols in the specific case of contra-flows (Thussu, 2007) such as kizomba. Those nations placed in weaker positions in political, economic and symbolic terms and in need of establishing their global market brand are correspondingly more likely to rely on whatever cultural industry that happens to succeed internationally. As I seek to demonstrate through the kizomba case, even those music and dance performances originally rejected as "foreign" and "unauthentic" by cultural authorities at the state level, may subsequently turn into symbols claimed and fiercely defended as properly national by the very same actors in the wake of its global success. In other words, global market dynamics return a greater impact as regards the definition of national symbols for nations that experience weaker economic and political positions within the international context. For the empirical case of kizomba, Angola constitutes a country that only became independent in 1975, following a long national independence conflict, followed by twenty-eight years of civil war that devastated what infrastructures then existed, damaged social institutions and left the country in extremely precarious conditions. During the first decades of this century, while the Angolan state has tried to recover and rebuild the country, the international financial crisis had a major impact on Portugal, resulting in a particularly high unemployment rate. In this international context, diverse actors sought to capitalize on a dance that dancing crowds worldwide associated with modernity and cosmopolitanism in order to gain and/or boost their own global visibility: whether the Angolan state, the city of Lisbon or the individual performers competing in the transnational kizomba industry. This paper sets out the context in which these national claims make sense and are duly contested. Within this goal, this provides a description and analysis of some of the most relevant competing narratives on the nationality of kizomba: the discourses around "Angolan" kizomba, "Cape-Verdean" kizomba, "African" kizomba, global kizomba and "Lusophone" kizomba.

The kizomba case holds particular interest to analysis of just how the nation is imagined through kinetic signifiers that develop in transnational contexts for several reasons. First, this dance represents an interesting counter-example in the literature of dance globalization as kizomba was first commodified and exported from a peripheral South European city (Lisbon) instead of a global city (Sassen, 2005). For this reason, kizomba emerged from a less advantageous position in the global dance industry, turning it into a contrasting case with those dances commodified in and globalized from New York or Paris, such as salsa, hip hop or tango. In this sense, the transnational spread of kizomba may be considered an example of what Thussu calls a "contra-flow" (Thussu, 2007). A contra-flow is a cultural trend exported from a peripheral region in the world economy whose success challenges hegemonic circuits of globalization, such as the "Americanization" paradigm ${ }^{4}$. From this perspective, even though kizomba's

4 Some of the examples explored in Thussu's volume are Indian Bollywood films and Brazilian telenovelas. 
success is not comparable to those genres that have become mainstream through these hegemonic flows, such as hip hop, we nevertheless reference the "great success" of kizomba throughout this paper. By this, we refer to its remarkable though marginal international spread within the context of a highly competitive global market. Second, the dance represents an unusual case when compared with national ballets, "traditional" and "folkloric" dances, institutionalized and defined directly by state agents. Just as in the case of semba in Angola, this constitutes an example of nationalism "from below" based on everyday popular practices (Moorman, 2008; see also Pacini-Hernández, 2014). Interestingly enough, Angola claimed the performance as a national symbol only after it achieved global success. Third, its history of deep transoceanic connections involves a complex process of métissage, resulting in a multi-layered performance that turns kizomba into great material for symbolizing many different and even contradictory imagined communities (Anderson, 1983; Turino, 2000). As we shall see, Angola, Cape Verde, and even a vague idea of "Lusoland" (De La Barre and Vanspauwen, 2013) are imagined through kizomba. In this sense, its swift globalization process has led to multiple appropriations in each local context alongside fusions with other dance styles. This furthermore drove aficionados/as to wonder about its nature and cultural origins, promoting intense transnational debates on online platforms such as Facebook and Youtube.

This interpretation arises from the theoretical framework of instrumental ethnicity (Cohen, 1969), a symbolic construction of the ethnic group that is strategically developed for marketing purposes (Comaroff and Comaroff, 2009). However, in order to avoid the dichotomy primordialism-instrumentalism (Banks, 1996), we follow Bentley's theory of ethnicity as practice (Bentley, 1987), based on Bourdieu's theory of practice and concept of "habitus" (Bourdieu, 1987). In this way, we also take into account how this strategic positioning affects definitions of the self and feelings of belonging and here making people feel proud, harmed, attacked and subject to emotional reactions in the kizomba debates.

The paper's structure is as follows: the next section explores the competing narratives registered within the scope of the global kizomba industry, within which the most relevant actors are the dance teachers competing to attract students. The site of conflict revolves around just who is and who is not legitimate for teaching the dance style coupled with discourses on the Angolan-ness, Cape-Verdean-ness or African-ness of performers and their performances. The third section focuses on analyzing the processes by which the Angolan state has claimed kizomba as an official national brand. In the context of competition for gaining visibility in the global economy, cities and states compete to place their respective "brands" in an advantageous position. In this context, festival organizers based in Lisbon have claimed that kizomba belongs to Lusofonia, a vague post-imperial notion that encompasses music and dance coming from the former colonies. The Cape Verdean state is taken as a counter-example that has not claimed kizomba as a national symbol, unlike certain national actors in the dance industry. In the concluding and final section, the argument reaches beyond the specific kizomba case to reflect on how relevant the global industries have become for shaping national symbols and the extent of the vulnerabilities faced by the former colonies in this transnational scenario. 
In terms of the music, commodified kizomba aficionados/as usually prefer the most recent style developed by a new generation of artists such as Anselmo Ralph, C4 Pedro or Mika Mendes since the 2000s. This new wave is characterized by a slower tempo, the influences of global beats such as $R \& B$ and relies more heavily on digital sounds and effects than the generation closer to the Antillean zouk of the 1980s. Attending DJ sessions has become the most common way of consuming kizomba music in the nightlife. Correspondingly, the former tradition of live concerts has lost relevance having turned into a cycle of sporadic events; even when performing at international kizomba congresses, artists usually do play-back. As I witnessed during fieldwork, this difference has reflected on the politics of social distinction through which lovers of the "traditional" zouk culture pejoratively label the new kizomba wave as "kizombinha" ("little kizomba" in Portuguese). On the other hand, commodified dance aficionados/as generally do not display any great interest in either Antillean zouk or the older kizomba styles that directly derived from it.

As regards the dance form, one of the most appealing features of the commodified version of kizomba consists of the proxemics unusual in the dance school context ${ }^{5}$ : in the basic step, the two partners dance in a close embrace bringing about tight body contact. In the slower section of the music called "tarraxinha", the beat of the music is accompanied by coordinated slow and sinuous rhythmic movements with the partners' hips in close contact, sometimes ending up touching around the hip area - navel shocks in the dance parlance ${ }^{6}$. These traits, combined with the aficionados/as' habit of closing their eyes on the dance floor, turn the dance into quite an intimate experience frequently shared with unknown partners. These characteristics are often interpreted as "too sexual" by many other dance aficionados/as that deter them from practicing it ${ }^{7}$. Throughout the commodification and globalization process, teachers gradually introduced new acrobatic and complex steps stemming from other ballroom styles, just as Waxer (2013) describes for the case of salsa or Apprill (2008) for the case of $\operatorname{tango}^{8}$. Resulting from these multiple fusions and appropriations, the kinetic languages of commodified kizomba dance floors evolved along diverging paths. In the context of this burgeoning market, many diverse social agents such as musicians, teachers, the city of Lisbon and the Angolan state tried to capitalize on kizomba's success, resulting in legitimation struggles around authenticity and the nationality of the dance.

5 Unlike tango, the physical connection is established not only at the chest level but also at the hips and belly level.

6 The "navel shock" has turned into an important kinetic symbol of African-ness for the aficionados/as community. See Travassos (2004) for an overview of the "navel shock" (umbigada in Portuguese) family of dances, the meanings of fertility usually attached to it by outsiders and scholar critiques of these simplistic interpretations.

7 During fieldwork, I witnessed how bachata, tango and salsa aficionados/as in Spain and Portugal considered kizomba too sexual, establishing a distinction as regards their own dance genre that they deem "cleaner" and more respectable. On the other hand, kizomba aficionados/as feel proud of their capacity to step beyond what they consider conservative prejudices. The reader can find a visual example of a commodified performance by the artistic couple Afrolatin Connection that became extremely popular during the fieldwork period at: https://www.youtube.com/watch?v=ISJ6g-OfXC0\&list=RDISJ6gOfXC0\&start_radio $=1 \& \mathrm{t}=2$

8 In order to provide the reader with a visual example of the commodified version of the dance, I suggest watching the following Youtube video. Performed by the teachers Albir Rojas and Sara López in 2012, it became rather popular among kizomba aficionados/as during fieldwork: https://www.youtube.com/watch?v=29DT-71bk-M 


\section{Methodology}

This article stems from my postdoctoral research project "Dancing ethnicities in a transnational world"9, which contained the general objective of exploring the diverse ways in which ethnicity is constructed out of social dance contexts. Within this objective, between 2012 and 2015 I carried out fieldwork in kizomba dancing contexts in Spain and Portugal: primarily participant observation in "African discos", kizomba dance schools and kizomba international festivals. During the first year of fieldwork, I took dance lessons and followed the weekly circuit of kizomba aficionados/as in Madrid and the yearly ritual of the festival cycle taking place throughout Spain. During the second year in Lisbon, I visited some of the best known clubs in the city and attended Africa Dançar and Keta festivals. I did participant observation in school contexts such as Jazzy Dance School, Braço de Prata, and cyclical workshops organized at the B.leza and Barrio Latino clubs. This was complemented by thirty-three in-depth interviews with DJs, dance teachers, dance students, disco owners, promoters and the public relations of kizomba events. In order to enrich this collection of materials, I searched for and transcribed a total of 109 public interviews with kizomba artists and teachers working in diverse countries available from diverse websites, the radio (mainly RTP Africa, a Portuguese channel focused on the PALOPs and their presence in Portugal) and television (mainly TPA, the Angolan public television channel).

Regarding my positionality in the complex postcolonial field of Lisbon, I naively expected that I would be regarded as an outsider from a foreign country (Spain), disconnected from the interethnic tensions of everyday life and relatively free to move among different social groups. Nonetheless, I was mostly perceived as a member of another category: "White European aficionada" with no personal relationship with Africa. On the one hand, this helped my integration process into groups of kizomba learners, who automatically accepted me as "one of them", making this dimension of the fieldwork smooth and easy. On the other hand, some "African" people were reluctant to participate in this research as they did not trust the intentions of someone they perceived as a "White" aficionada, thus making social relations harder than expected. Moreover, I also raised some suspicions among certain teachers who interpreted my research activities as a means of gaining an "expert" position in the kizomba industry and thus becoming a new competitor for them. In conclusion, building trust relations became extremely hard due to two methodological shortcomings: the first, a strategy that started out with commodified environments, placing me automatically as a kizomba aficionada in the eyes of participants. This role provided a comfortable position, easy to recognize by research participants but also closed many doors when trying to reach people deeply involved in the kizomba industry or unhappy with the prevailing state of affairs. Secondly, an initial misleading perception of how deep the postcolonial interethnic conflict was, how difficult it would be to negotiate my position in such a mined field and how this would impact on the whole research process.

9 This postdoctoral project was funded by the FCT (Fundação para a Ciência e a Tecnologia), Government of Portugal. 


\section{Competing Narratives in the Global Kizomba Industry}

The global kizomba industry concept arises out of the notion of the "global salsa industry" developed by McMains (2016) and Hutchinson (2014) to encapsulate the transnational circuits of dance teachers, dance schools and international festivals. Hence, this also reflects how the visibility salsa acquired the global level through performances and classes at clubs, restaurants and festivals (Pietrobruno, 2006) benefited the new kizomba industry. Moreover, the historical connections between the Caribbean and Africa made the target audience of salsa lovers feel a sense of familiarity with the beat of the music. According to Kabir, there has been a constant circulation of musical influences between Africa and the Caribbean since at least the 1920s (Kabir, 2018). The kizomba industry developed from the early 2000s onwards and it had spread virtually all over the world in less than a decade, following in the wake of the global salsa circuits and gaining visibility on Internet platforms such as YouTube and Facebook (Soares, 2015). In spite of the peripheral position of Lisbon as the origin of the kizomba phenomenon, its globalization process was so fast that it is nowadays possible to find a kizomba dance school in almost every corner of the world.

The first and most remarkable point is that kizomba did not need to establish its own international market structures from the outset as it integrated into and followed the already existing global salsa circuits and networks. The dance was made available in salsa schools, venues, and international salsa congresses ${ }^{10}$ and often by salsa teachers. Hence, connections with and good knowledge of the global salsa industry circuits proved more important to success in this market than the dancing skills acquired in "African" labelled cultural contexts. Moreover, the financial crisis left many aficionados/as labelled as "White" and "Portuguese" unemployed and led many to become kizomba teachers. As a consequence, they found themselves competing with their former instructors and other colleagues from the PALOPs labelled "Black" and "African". Beyond Portugal, certain immigrants from (PALOP and non-PALOP) African countries enrolled in the new global kizomba industry. However, resulting from the combination of the aforementioned factors, the benefits of this burgeoning transnational business very often reached people connected to the salsa world but any without the direct relationship to the African continent held by the immigrant performers, usually labelled "Black" and "African" in their respective European cities of residence. For example, in Spain, most kizomba teachers were "White" or "Latino" salsa teachers of Spanish or diverse Latin American nationalities without life experience in any African country or kinship ties with families residing in Africa. This unexpected scenario, resulting from structural inequalities and the harsh competition to attract students, was the context in which bitter legitimation struggles around the ideas of authenticity and Africanness made sense.

10 The event model, created for the First World Salsa Congress in Puerto Rico in 1996 (Hutchinson, 2014: 6-7; McMains, 2016), includes workshops, an international competition, professional performances, social dance venues and the merchandising of products such as shoes, clothes, CDs or DVDs. 
Following its swift expansion, learners and teachers began asking questions about just what they were dancing. This point of departure represents what we may term a symbolic deficit: a newly emergent culture of dancing practices is on the rise and there thus arises the need for its symbolic elaboration. Participants need a mythology, a history of origins on which the main leaders agree. These basic symbolic needs were not being fulfilled and we instead encounter an open struggle over this symbolism waged among the most respected teachers. The narratives on "Angolan", “Cape Verdean", "African” or global kizomba constitute some examples of these self-legitimating stories. Debates on the origins and nationality of the dance started and became particularly heated when following a logic of instrumental ethnicity (Cohen, 1969) for marketing purposes (Comaroff and Comaroff, 2009).

The fact that the term kizomba was chosen in dance schools, leaving out other labels widely used in "African discos" such as passada or batida, held negative consequences for some teachers in the context of these legitimation struggles. Dance labels constitute devices through which many statements on national/ethnic belonging are made (Guilbault, 1997) and it is common to search for the origins of a dance by starting with the etymology of its term of designation. In this sense, it does seem clear that the word kizomba is a Kimbundu term, with Kimbundu the language spoken by one of the three biggest ethnolinguistic groups of Angola, the "Ambundu" people (Moorman, 2008). In general terms, it means "party" and "social encounter" (Moorman, 2008; Cidra, 2010b, Chatelein, 1896). One of the oldest references I have found came from Chatelein, an anthropologist who did fieldwork in Angola at the end of the nineteenth century. In a paper published in 1896, he refers to kizomba as a society gathering for ritual purposes, especially funerals:

"After the official abolition of slavery (or possibly before), the freedmen of Loanda organized themselves into tribal orders or lodges for the purpose of mutually helping each other and keeping up some traditional practices of their respective tribes [...]. These societies are called 'Bandeiras' in Portuguese, and 'Bandela' in native parlance. The genuine Ki-mbundu name is Kizomba, that is, dance. They have regular meetings in which they dance according to national customs and raise a collection. This goes in a box only opened when a member dies; then the money is spent on dancing, eating and drinking, a funeral feast (tambi), which lasts as long as the money collected holds out."

(Chatelein, 1896: 57-58)

However, these societies also acquired a dimension of cultural resistance with their purpose of mutually helping each other and maintaining some of the traditional practices among these diverse social groups that were regarded with suspicion by colonial officers. In this way, the term kizomba thus condensed several meanings: dancing, belonging to a social group, ritual encounter, party, and resistance to colonial rule. One century later, as youngsters headed to parties in Angola in the 1980s, they used to say "we're going to a kizomba", and the corresponding music and activities became associated to the general concept of kizomba (Cidra, 2010b). In the postcolonial context of Lisbon, the racism suffered by people labelled "African" in their everyday lives once again turned these dancing encounters into contexts of cultural resistance. According to the artist Eduardo Paim, the official birth of the word for specifically designating a musical style took place when a journalist asked Bibi, the percussionist in his 
band", what kind of music they made. His answer was "kizomba music" (that is, music for partying). From then onwards, the term started to spread as a label for speaking about popular party music made in the Angola of those times ${ }^{12}$. In this discursive context, the widely consumed and danced styles labelled cabozouk, afro-zouk and the like, produced in Africa and by "African" artists living or travelling to Europe, were considered something apart from a phenomenon imagined as specifically "Angolan": kizomba. Hence, with kizomba a Kimbundu term, some "Angolan" teachers claimed that the dance formed part of their own culture and they were consequently the only persons fully legitimate to teach it. Other teachers (mainly from Cape Verde) maintained that this dance was not only "Angolan" but rather constitutes an "African" product and hence their own performances require due recognition as authentic. In addition, some teachers in Europe claimed the style was a global dance and thus "property of the world" with their own performances correspondingly also deemed legitimate. We are here going to explore some of the main voices in the debate over the national property of kizomba through several short stories taken from the field. As the following actors hold authority for dance aficionados/as all over the world, their arguments correspondingly constitute an essential input to the context in which the state of Angola later decided to make its national claims: thus, the state strategy built on opposition, support, rejection or nuanced agreement with the following widespread perspectives.

We begin with Carlos Vieira Dias alias mestre Pechú, considered one of the very first kizomba teachers and, now into his forties, one of the oldest. For these reasons, he stands out as an authority for most kizombeiros/as ${ }^{13}$. He belongs to the Vieira Dias ${ }^{14}$, a well-known family of musicians that played an active role in the Angolan independence process. Although without any formal training in dance, he participated in Luanda's carnival troupes and dance competitions from a very young age. He was also a member of Kilandukilu, a traditional ballet company, with which he toured Europe. Later, in 1996, he arrived in Lisbon and took various jobs to make a living, such as in civil construction as is the case with most immigrants from Africa. He then decided to recreate the ballet company Kilandukilu with youngsters living in the city and was later able to find a job opportunity as a "traditional Angolan dance" performer. A few years later, he was invited to hold a kizomba workshop; at first, he took this as a joke before then later accepting. Whenever someone asks him about the origins of this dance, he explains he is writing a book on the real history of kizomba. According to his perspective, this dance is one hundred per cent "Angolan"; born in Luanda (the capital) and its surroundings during the 1980s and he experienced this style himself directly when younger. According to his perspective, kizomba derives from semba, which is itself a dance style inheriting still older Angolan dances such as massemba, rebita, kazekuta or kabetula.

\footnotetext{
11 A popular band in Angola since the 1980s. This interview is available online: http:// angodebates.blogspot.com/2011/05/eduardo-paim-sou-o-precursor-da-kizomba.html

12 Interview with Eduardo Paim: http://www.opais.net/pt/dossier/?det=21059

13 Kizombeiro (male) and kizombeira (female) are the labels that aficionados/as commonly use to refer to themselves.

14 See Moorman (2008) for further details about the family, the band Ngola Ritmos and its role in the Angolan independence process.
} 
Hélio Santos is a kizomba teacher of Cape-Verdean origin who lives in Lisbon. His background is in contemporary dance and the "traditional dances of Cape Verde". He arrived in Portugal in 1999 after touring with a "Cape Verdean" contemporary dance company (Raiz Bipolon). He started teaching "traditional Cape Verdean dances" before he was invited to teach kizomba and join the first group of artists in this experiment. Within the context of an interview about his life story, he told me his version of this dance's history. According to him, its name is passada in Cape Verde and its deep roots reach back to "Cape Verdean folkloric dances", such as coladera, mazurka, funaná, san jon, tabanka, landum, batuko, and contradança among others. Clearly, there are thus at least two different genealogies of the dance built up in order to support a particular idea as to its national property. Both narratives establish deep roots distant in time. Indeed, the deeper in time the history is, the more powerful it becomes in symbolic terms.

Zé Barbosa is a dance teacher who left Cape Verde and arrived in Portugal in 1998 , through an artist exchange programme between the two countries ("Preto no Branco"15). He covers diverse artistic domains such as theatre, dance and painting. At the end of the 1990s, after performing "Cape Verdean traditional dances" professionally, he was invited to teach kizomba at a dance school. The promoter of this idea was Quim, a producer labelled "White" and "Portuguese" by research participants, who also turned to Petchú, Hélio and others. Quim usually frequented "Angolan discos" in Lisbon and the word he had heard for referring to the dance was kizomba. Nevertheless, Zé Barbosa called it passada and decided to label his workshops kizomba na passada ${ }^{16}$. As one of the first, alongside Petchú, he is one of the most respected and recognized teachers in the field. In any case, kizomba was the label chosen in the commodification process. During a kizomba festival in Spain (Feeling Festival 2012), Beatriz Soto, a kizombeira who makes interviews in festivals and posts them on Youtube, asked Zé Barbosa about this debate on the Angolan-ness vs. Cape-Verdean-ness of the dance. This is what he replied:

"I am not against Angolans saying that kizomba is from Angola. Cape-Verdeans never said anything like that. Guineans never said anything like that. I think, I am sure that some time ago, the only Angolan we know who was teaching kizomba was Petchú. The others didn't teach Europeans to dance kizomba. And now all that work that we have been doing for a long time to reach this point involved people from diverse countries teaching. Now,

Angolans should be a bit more humble and say: kizomba is not only Angolan, because the Cape-Verdean didn't go to Angola to learn kizomba, Guineans didn't go to Angola to learn kizomba. Guineans call kizomba batida, they learnt it in Guinea. Cape-Verdeans call it passada, they learnt it in Cape Verde. Angolans call it kizomba, they learnt in Angola. This is not the property of one or another. Most of the music comes from Cape Verde. But Angolans say they dance better. It's ok [...]. I feel so sad when I go to teach somewhere, in a different country, and I am asked: 'Are you Angolan?' And I say 'No', 'Then you cannot teach it because you are not Angolan'. What is that about?" (Interview with Zé Barbosa by Beatriz Soto ${ }^{17}$, posted on 22/03/2013)

15 "Black on White".

16 This translates as "kizomba in a set of steps".

17Translated from the original mix of Spanish and Portuguese into English by the author. This interview is available online at: https://www.youtube.com/watch?v=5EF2GzpqE0g 
This discourse Zé Barbosa protests against is based on a hierarchy of values (Díaz de Rada, 2007) established to claim, among other aspects, the right to enjoy preferential relationships with potential dance school clients. Within the immigration context of Lisbon, when research participants used the category "African", they referred to people born in the PALOPs and their offspring. This term was generally applied to contrast with the label "Portuguese" to foster a sense of groupness; in this field of commodified dancing practices, this "African" group gets divided into categories of legitimacy and levels of performance, delimiting better or worse access to the resources of these "Portuguese" people. This is what Abner Cohen describes in his classical theory as instrumental ethnicity: the production of difference with an instrumental goal (Cohen, 1969) ${ }^{18}$.

In the 2000s, kizomba grew constantly and rapidly in Portugal, far more than might otherwise have been expected, with some students deciding to start teaching. As previously mentioned, some of these "Portuguese" teachers, without any life experience or kinship ties with the PALOPs, became so popular and valued that they got compared with their "African" labelled peers. This happened to our next actors, Afrolatin Connection, a "Portuguese" artistic couple based in Porto who first learned kizomba with Petchú: at some point, they began receiving invitations to kizomba events and festivals that Petchú did not receive. Moreover, in the context of the prevailing economic recession, some kizomba aficionados/as lost their day jobs and decided to take up giving kizomba lessons in order to earn some income. In other words, teachers labelled "African" now encountered competition they had never expected: from their own "Portuguese" students. Let us consider the story of Afrolatin Connection: Ricardo Sousa and Paula Loureiro are a couple of dancers who began working together in salsa schools in 2000. When Petchú started teaching kizomba in the late 1990s, they attended his workshops and focused on this new dance. In 2005, they launched their own professional project, Afrolatin Connection in Porto: they set up their professional dance company, their own dance school, a bar called Muxima ${ }^{19}$ and also promoted kizomba events (for example, the annual Ta Fixe Festiva( $\left.{ }^{20}\right)$. They became extremely successful and opened the door for other people labelled "Portuguese" to feel confident and establish their place in the kizomba field. Other people across Europe effectively followed similar paths. The competition thus became harder and the debate over the legitimacy for teaching kizomba became ever bitterer.

On the evening of $9^{\text {th }}$ December 2013, I was invited to dinner at Petchú's house. Some of the guests were kizomba teachers born and raised in Angola and working in European countries such as Germany and the Netherlands. One of them said it was urgent for all "Angolan" teachers around the world to get together in order to claim the Angolan-ness of kizomba. "We need to join our forces around a leader, and it should be Petchú, the one who started all this." Otherwise, he feared, "non-Angolan" people would take over the market and promote unauthentic styles of the dance. As an example of this threat, he commented on something he had observed in the last international kizomba

18 Nevertheless, the complex struggles over labelling practices should not be reduced to the economic dimension (Guilbault, 1997).

19 It means "heart" in Kimbundu with the concept holding a deep meaning in Angola. 20 A slang expression meaning "that's cool." 
congress he had worked at: "I was looking at the dance floor in astonishment, everyone is now dancing like Albir ${ }^{21}$ !" This consequence involves the legitimacy of "non-Angolan", and more especially "non-African" teachers, being cast in doubt. In the documentary $A$ minha banda e eu, a recent film on kizomba and semba culture in Angola, produced by Inês Gonçalves, Bruno Sousa (Afrolatin Connection member) expressed himself as follows:

“We know Angolans are rather nationalist but what is ours, is ours. And they just try to imitate us, but we are the ones who do it right. This is a characteristic of Angolan people. Whether you want it or not [...], we are linked historically. There was already much fusion, many Portuguese people living in Angola because of colonization and all that, many Angolan people living in Portugal, and that's a reality, then it's normal that there are cultural exchanges. [...] In the beginning, I felt, in my personal experience, I felt... not racism but in that kind of line... It starts out with: kizomba is not something to be taught, this was the general way of thinking. This is something you learn on the dance floor, in the family, this is not something to be taught. Even more so, by a white Portuguese man, a pula ${ }^{22}$ without any relationship to the country of Angola, what is he doing in our environment, and even more transmitting something that is not his own? But this is like everything. I fell in love with the culture. I invested seriously in getting knowledge and now I am suitable, I consider I am suitable for transmitting this information. But it's natural that there is always the feeling of "this is not theirs, this... We are the ones who know what we are doing." (Excerpt from the documentary A minha banda e e $u^{23}, 2013$ )

These kizomba school authorities were asked to set out rules not only for movements but also for the mythology of these dancing symbols. Students started demanding a coherent story behind the symbols they were embodying and consuming. In the meanwhile, in "African discos" all over the transnational space, there were many diverse ways of dancing, flexible rules of body movement that changed from context to context and from time to time, and a rich variety of meanings condensed around their respective attachments. How to create a simple and unitary history out of this? Some placed the origins in Cape Verde while others placed them in Angola. Some decided to set them down by writing works on the history of kizomba. Although to the best of my knowledge no one has yet published any book, many did state that they were working on this during interviews. Within the context of the symbolic struggle, this simply became a new strategy for fixing symbols and establishing themselves as the definitive authorities in the field.

In summary, a social dance, which was formerly associated with moments of relaxation and socialization through pleasurable encounters, turned into a source of conflict expressed in terms of national symbols by virtue of commodification and globalization. In this context, the Angolan Ministry of Culture tried to capitalize on symbolic associations with the kizomba phenomenon to better position itself.

\footnotetext{
21 A Kizomba teacher born and raised in Panama, based in Madrid and very popular on the global kizomba circuits.

22 Pula is an emic expression used to refer to colonizers ("Portuguese" people), and "white" people in general, in a slightly pejorative way.

23 Translated from the original Portuguese into English by the author.
} 


\section{Promoting a New "Angolan" National Brand}

Cities and nations compete to present themselves as attractive "brands" in the global economy in order to attract capital through both tourism and foreign investment. As we shall see throughout this section, the position the music and dance styles deriving from zouk occupied in the Angolan Ministry of Culture's emic hierarchy of values, and correspondingly their legitimacy as national symbols, changed dramatically on account of the global spread of the kizomba industry. Initiatives such as support for television programs stressing the Angolan-ness of kizomba or introducing kizomba conferences and performances into the national celebrations organized by Angolan embassies in European cities emerge among the various examples of this kind be explored in this section. Interestingly enough, even though this national narrative echoes with the discourse on the strictly "Angolan" nature of kizomba produced by some teachers working in the global dance industry, neither agent (the government and the artists living in the diaspora) coordinates their voices. On the contrary, they even clash and engage in competition under certain situations. I explore two contrasting examples below: the first stems from Cape Verde, where the tourist sector has made no official national claims on this dance style, even though certain "Cape Verdean" kizomba teachers living in European cities do make such statements. The second case arises from the city of Lisbon, where the festival organizing sector has put forward some indirect claim on the centrality of Lisbon to kizomba that to a certain extent echoes the discourse of "Portuguese" kizomba teachers.

In 2013, the dance promoter Inês Pinto launched the on-line platform "Kizomba Nation" in order to foster the spread of kizomba and improve transnational connections among professionals and aficionados/as (Soares, 2015), an initiative that gained backing from the Angolan Ministry of Culture. The phrase "Kizomba Nation" refers to the group of practitioners all over the world imagined as a single national community (Anderson, 1983) ${ }^{24}$. The project's objectives involved collecting all the information available about kizomba events and dancing communities worldwide alongside research into the origins and history of the dance form. What made this especially appealing to the Angolan government is that through this process of compiling knowledge, one of the stated objectives involved producing an official unitary and defining version of kizomba in which the Angolan-ness of the dance represents its foundational basis. Within this strategy, a group of the most influential kizomba teachers working in Europe (including Petchú, Zé Barbosa and Albir Rojas), as well as promoters (for example, Beatriz Soto) were invited by the government to meet in Luanda. The objectives here were transmitting the state's official story about the Angolan origins and characteristics of kizomba and rendering support to the transnational Kizomba Nation network for promoting the dance from this univocal perspective. Within this goal, a panel of experts designated as authorities by the state's cultural department gave talks for which these successful dance teachers were

24 In the same line, the festival of reference for the global community of aficionados changed in 2014 from Africadançar into Kizomba Nation. Nevertheless, according to Soares (2015) one of the objectives of this renaming was stating the relevance of Lisbon as centre of the kizomba global community. 
sat in attendance as listeners and learners ${ }^{25}$.

The main promoter behind this strategy was Jomo Fortunato, a consultant to the Minister of Culture, a literature specialist, art critic and professor at the University of Luanda. The project attained online visibility through a website (in Portuguese, English, French and Spanish), a Facebook page, a Youtube channel, an Instagram site and a Google Plus site. In addition, it incorporated a series of documentaries on the international kizomba boom broadcast weekly on the TPA channel to convey how the kizomba craze was evolving in different cities around the world ${ }^{26}$. This series clearly targeted fostering national pride in its "Angolan" audience by conveying how that part of "our Angolan culture" was gaining admiration all over the world. The promotional video for the first season included the following statement:

"Did you know that kizomba is taking over the world? A travel around European cities through this music and dance with the Angolan ginga ${ }^{27}$. Look at how Europeans take risks on their dance floors to the sound of kizomba. Kizomba Nation: the nation of kizomba."28 (Promotional video for the first TPA season of Kizomba Nation ${ }^{29}$ )

Nevertheless, the final goal does not involve promoting the dance itself as Jomo Fortunato has explained on several occasions. This strategy rather seeks to attract wider public audiences towards other aspects of "Angolan" culture (other dances, literature, music, etc.). In other words, this aims to feed and strengthen the national brand of Angola and ultimately to encourage tourism and other business flows. Indeed, in the beginning, the musicians that became authorities in Angola did not consider kizomba an "Angolan" genre. As demonstrated in the following excerpt from an interview with the musician Eduardo Paim, even Jomo Fortunato, the man who designed the Kizomba Nation project, was rather critical about kizomba:

Journalist: "The arts critic Jomo Fortunato said that kizomba was a poor imitation of zouk."

Eduardo Paim: "Why does he think that it is a bad imitation? Who told him it is an imitation? Let's start by saying that no one has that right. For that reason, one has to make assertions taking into account the consequences they may bring. It is easy to criticize, it is difficult to do. And we do: there you have the proof. Anyway, the rhythmic similarities are obvious..." (Online interview with Eduardo Paim) $)^{30}$

\footnotetext{
25 Some actors, actresses, images and voices from this event feature in this television program launched on the Public Angolan Television and available on Youtube: https:// www.youtube.com/watch?v=wbhcGMIDGto

26 For example, some programs were recorded in Munich, Madrid, Budapest, Moscow, Copenhagen and Cairo.

27 Ginga is a difficult to translate Portuguese word: something like a special way of moving. "Having ginga" represents a much repeated and relevant expression in the field and might also be translated as able to move gracefully and nicely from the emic perspective.

28 Translated from the original Portuguese by the author.

29 Video available on Youtube via the following link: https://www.youtube.com/ watch?v=yWGqJKvqH-M

30 Translation from the original Portuguese into English by the author. Available online at: http://www.opais.net/pt/dossier/?det=21059
} 
Following the success of kizomba at the global level, its status changed dramatically to the Angolan administration. It passed from being overlooked and disregarded as a foreign form of music and just a passing dance fashion to take up a full role in the set of national symbols. As such, it was performed and exhibited at official events such as national celebrations organized by embassies abroad. In other words, kizomba was validated through this visibility as Goertzen and Azzi (1999) assert for the case of tango. However, the promotion of kizomba by the Angolan state represents only one means of serving a broader plan for promoting a country that is now in the middle of its reconstruction process.

Angolan embassies have also played a role in spreading this message of the dance as a national emblem. When celebrating the National Day at the Angolan embassy in Madrid, kizomba performances made up part of the event. As part of fieldwork, I attended a kizomba dance contest at Bisú Lounge Club organized and promoted by the Angolan embassy. For the first time, I encountered "Angolan" youngsters outside the commodified circuit competing in an event of these characteristics. The embassy also provided support for the 2013 Open Kizomba Festival held in Madrid. Mr. Mixinge, the person in charge of the embassy's cultural section, gave a brief talk on the origins of kizomba to the audience before the competition started:

"Kizomba is a musical genre and also a dance style associated with the Bantu tradition, originally from the outskirts of Luanda. [...] That is the reason traditionalists don't like to see kizomba associated with other rhythms like salsa [...] But actually all great cultures in the world survive when able to reinvent themselves [...] The Angolan embassy will always be present to support events interconnected with this rhythm, this dance. Above all, we like to see you enjoying it as I hope you will do tonight." ${ }^{31}$

TPA (Angolan Public Television), watched by many people both in Angola and in the diaspora, has played an important role in transmitting this message of national pride through kizomba. For example, the dance competition in which couples compete to represent Angola in the final held in Lisbon every year is broadcast on the television show Janela Aberta ("Open Window"). In this program, a jury of experts comments on the quality of competitor performances, making statements on the proper ways of dancing and performing authentic "Angolan" kizomba. Another example comes with the television show Tchilar, which in 2010 broadcast a debate on the origins of kizomba. Four well-known artists from Angola were invited: Lito Graça, an old and respected percussionist, and three younger, famous singers Calo Pascoal, Nelo Paim and Jandira Dos Santos. The following excerpts of the debate convey the main points of symbolic conflict:

Lito Graça: “For me, kizomba as a music style does not exist [...]; for me it's zouk. [...] If you write it on a stave and you see the pattern... and taking into account that what defines the musical style is the percussive base, with a cord instrument that is the bass, you're going to see a written pattern of kizomba and a written pattern of zouk and it's the same thing, the rhythmic base is the same."

Calo Pascoal: "[...] but Antilleans wouldn't accept that what Angolans sing, even with their instrumental base, is zouk."

31 Translated from Spanish by the author. 
Nelo Paim: “[...] For me, Antillean music, zouk, is the music made by Antilleans, kizomba is made by us."

In order to convey an idea of the nationalist feelings underlying this heated debate, there are below two of the comments posted when the program launched on Youtube. Some people had become rather upset about Lito's statements about kizomba being equivalent to zouk in musical terms even though he was one of the oldest, most experienced and most respected musicians in the country:

Comment 1: "Unfortunately, there are Angolans that give out a negative image of Angola, making improper claims, and putting us down instead of putting value on what is ours."

Comment 2: "this old man (referring to Lito Graça) is stupid and does not know anything... Kizomba is an Angolan music style, get on the Internet and google kizomba's origins... Old people like this are just fucking Angolan people that love their music and they can't cope with what is really Angolan ${ }^{32 . "}$

As stated in the theoretical framework, the actors and actresses encountered in the field display heated reactions so that the dimension of instrumental ethnicity must not be understood as a pure and cold rational exercise. On the contrary, this triggers passionate feelings. When faced with alternative ethno-national constructions of their beloved embodied symbols, social agents feel attacked and react in defensive ways.

Cape Verde constitutes an interesting contrasting case in this context. Even though many "Cape Verdean" teachers have contributed to the conflicts within the global kizomba industry by arguing that their performance is legitimate, their government has not invested in this strategic approach for promoting the country. In Cape Verde, within the context of the 1960s independence movements, the musical styles converted into official symbols of the new nation were mainly morna and coladera, those that then represented the social elite (Cidra, 2011). It was only later, during the late-1970s and the early 1980s, that funaná, cola san jon and tabanka, popular genres among lower classes, got integrated as legitimate symbols of the nation (Cidra, 2011). In the second half of the 1980s, zouk became fashionable and people commonly named it after the generic term passada (set of steps) used to dance the style. However, the term passada does not appear in the list of "Cape Verdean" dances drafted by intellectuals and experts: batuco, lundum, mazurka, contradança, morna, funaná and coladera are those most cited as proper "Cape-Verdean" dances (Tavares, 2005). In the 1980s, musicians called the new fashionable music style zouk, zouk love, or ghetto-zouk, thereby recognizing the clear influence of zouk music in these labels (Hoffman, 2008). Just as happened in Angola, traditionalists and nationalists considered the style a foreign influence that might pollute the pure essence of national music:

“The modern generation born in the diaspora has chosen a controverted style as regards its positioning in the classificatory table of Cape Verdean music. It is a rhythm

32 Translated from Portuguese by the author. 
originated in the USA and the Netherlands, more influential in the latter, called 'zouk love' by young people. As its name indicates, it is no more than a reproduction of Antillean 'zouk', therefore, according to critiques, distant from the vernacular Cape Verdean line. [...] These objectors defend that the influence of foreign music, in this appropriation, distorts Cape Verde." (Tavares, 2005: 39)

Even though music labelled as zouk love made by artists who emigrated from Cape Verde to European cities became extremely popular at the international level (becoming the main soundtrack of the kizombeiros' field), there have been no nationalist claims on the Cape-Verdean-ness of the music by state representatives. One of the reasons may stem from the already existing, well-established and powerful musical symbols of Cape-Verdean-ness in the global economy. In the early 1990s, "Cape Verdean" music entered the "world music" market with great success (Cidra, 2010a) and cultural policies remained focused on promoting these established music styles.

In conclusion, a social dance that had been largely ignored by state governments changed its status on turning into an attractive global commodity. Bureaucratic agents belonging to a nation-state (Angola) tried to associate the dance's aura of modernity and cosmopolitanism to their own brand. In this way, the debates that emerged in the global kizomba industry found an echo at the bureaucratic level of official national symbols. As I explore in the concluding section, this global contra-flow constitutes an especially interesting case for reflecting on contemporary processes of nation building in late modernity.

\section{Conclusion: Contra-flows and the Role of Global Industries in the Shaping and Transnational Circulation of National Symbols}

Global industries have gained a greater influence over the definition of national symbols in late modernity. In a context of neoliberal capitalism, cities and nations compete for visibility in the global market and symbols turn into potential factors for promoting successful branding processes. This has an impact on nation building both at the state level - in terms of the national strategy - and at the bottom level in the ways citizens represent the imagined community to which they ascribe themselves, making them feel connected to the symbols attaining success in the global market.

Ever since the introduction, I have defined kizomba as an example of a contra-flow (Thussu, 2007), an uncommon case of dance globalization that challenges the hegemonic theories positing the circulation of only mainstream genres. Throughout the paper, I have thus described and analysed the great impact that such success - however marginal it may appear compared with global styles such as hip hop - has had on the building of national symbols. The need to belong to a society that exports successful cultural brands become especially strong following colonial trauma, when most of the images reaching the global level interlink with poverty and backwardness, placing the country outside of modernity in the international imaginary. Under such conditions, successful contra-flows of cultural industries associated with modernity and cosmopolitanism acquire great powers for shaping processes of collective self-definition. 
From the legitimation struggles that we have described and analysed above, we may propose at least three conclusions: first, dances resulting from deep historical connections among peoples symbolically constitute what Jennifer

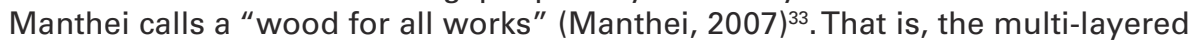
character of performances such as kizomba provides the material for building the symbols by diverse social groups. We have seen how the same performance can be interpreted as Angolan-ness, Cape-Verdean-ness, African-ness, the postcolonial centrality of Lisbon, global cultural heritage and world unity, among others. These kinetic symbols easily acquire new meanings, associating and interconnecting dense layers of embodied forms of belonging. However, these constructions are not random and must always be understood within the specific context, the historical moment and symbolic battlefield in which they make sense.

Second, from the empirical descriptions provided, we may observe how, when nations are imagined "from below", through popular dancing symbols (Moorman, 2008), commodification and globalization are sometimes experienced as symbolic attacks against national feelings. The transformation processes involved in commodification lead to cleaning the dance of any associated conflict, something particularly essential given they are charged with collective pride against the racism experienced in the societies of European dance consumers. Moreover, they tend to simplify the aforementioned dense meanings in order to obtain an easy entertainment product for the sake of consumer enjoyment. The strong reactions we have witnessed throughout the paper should thus be read not only in their dimension of rational and calculated strategies for improving the benefits gained from a given competitive industry but also in the emotional outrage dimension expressed by actors and actresses who feel their national feelings are attacked through frivolous interpretations of their culture.

However, we need to stress that the globalization process which led to such modification and misinterpretation also built the scenario in which, for some, kizomba dance became a relevant symbol of belonging, something worth claiming, defining and defending. In this sense, it is important to remark how relevant global industries have become for symbolic nation building in neoliberal late modernity, especially for those nations which hold weaker positions in the global economy. Before the commodification of kizomba dance, the government of Angola had paid little attention to the style, with reputed "Angolan" musicians having even pejoratively termed it "foreign music"34, "African" immigrants danced to it in discos in Lisbon without overly thinking about the labels they were using (or not using any label at all). In other words, as this paper demonstrates, the way that global industries render kinetic cultures visible may lead to changes in the emic hierarchies of value through a mirror effect in what Goertzen and Azzi (1999) term "validation through visibility". In this way, performances considered irrelevant or "unauthentic" in national terms may come

33 Manthei uses this expression in analysing the symbolic construction of the "Brazilian Mulata".

34 Eduardo Paim, one of the pioneers of kizomba music in Angola, stated in several interviews how he was accused of imitating foreign musical fashions by the older generation of musicians. 
back transformed into national symbols. In conclusion, global capitalism has become extremely powerful in defining national senses of belonging in a period of growing transnational connections.

\section{References}

Almeida Miguel Vale De (2008) Portugal's Colonial Complex: from Colonial Lusotropicalism to Postcolonial Lusophony, [online] last checked on 21/06/2018. URL: http://miguelvaledealmeida.net/wp-content/uploads/2008/05/portugals-coIonial-complex.pdf

Anderson Benedict (1983) Imagined communities. Reflections on the Origins and Spread of Nationalism, London, Verso, 160 p.

Apprill Christophe (2007) Tango. Le couple, le bal et la scène, Paris, Autrement, $154 \mathrm{p}$.

Banks Marcus (1996) Ethnicity: anthropological constructions, London, Routledge, $224 \mathrm{p}$.

Baumann Gerd and Gingrich Andre (Eds.) (2004) Grammars of identity/alterity. A structural approach, New York, Berghahn Books, 219 p.

Bentley Georges (1987) Ethnicity and Practice, Comparative Studies in Society and History, 29 (1), pp. 24-55.

Bourdieu Pierre (1987) Espace social et pouvoir symbolique, in Pierre Bourdieu, Choses Dites, Paris, Les Éditions de Minuit, pp. 147-166.

Brubaker Rogers (2002) Ethnicity without groups, European Journal of Sociology, 2 (2002), pp. 163-189.

Chatelein Heli (1896) Angolan customs, The Journal of American Folklore, 9 (32), pp. 13-18.

Cidra Rui (2011) Música, poder e diaspora. Uma etnografia e história entre Santiago, Cabo Verde, e Portugal, Unpublished Doctoral Thesis, FCSH, New University of Lisbon.

Cidra Rui (2010a) Migração, Música e, in Salwa Castelo-Branco Dir., Enciclopédia da Música em Portugal no Século XX A-C, Lisbon, Temas e Debates/Círculo de Leitores, pp. 773-793.

Cidra Rui (2010b) Kizomba, in Salwa Castelo-Branco Dir., Enciclopédia da Música em Portugal no Século XX A-C, Lisbon, Temas e Debates/Círculo de Leitores, p. 674.

Cohen Abner (1969) Custom and Politics in Urban Africa: A Study of Hausa Migrants in Yoruba Towns, London, Routledge and Kegan Paul, 252 p.

Comaroff Jean and Comaroff John (2009) Ethnicity, Inc. On the affective economy of belonging, Chicago, University of Chicago Press, $234 \mathrm{p}$.

De La Barre Jorge and Vanspauwen Bart (2013) A Musical Lusofonia? Music Scenes and the Imagination of Lisbon, The World of Music (New Series), 2 (2), pp. 119-146. 
Díaz de Rada Ángel (2014) En el nombre del pueblo: una reflexión para la crítica de los etnónimos en la escritura antropológica, in María Cátedra and Marie José de Villard Eds., Saberes culturales, Barcelona, Bellaterra, pp. 181-199.

Díaz de Rada Angel (2008) ¿Dónde está la frontera? Prejuicios de campo y problemas de escala en la estructuración étnica en Saapmi, Revista de Dialectología y Tradiciones Populares, LXIII (1), pp. 187-235.

Díaz de Rada Angel (2007) Valer y valor. Una exhumación de la teoría del valor para reflexionar sobre la desigualdad y la diferencia en relación con la escuela, Revista de Antropología Social, 16, pp. 117-158.

Goertzen Chris and Azzi Maria Susana (1999) Globalization and the Tango. Yearbook forTraditional Music, 31, pp. 67-76.

Guilbault Jocelyn (1997) The Politics of Labelling Popular Musics in English Caribbean, TRANS-Revista Transcultural de Música, 3, [online] last checked on 05/03/2013. URL: https://www.sibetrans.com/trans/articulo/265/the-politics-of-labelling-popular-musics-in-english-caribbean

Guilbault Jocelyn (1993) Zouk: World Music in the West Indies, Chicago, The University of Chicago Press, 279 p.

Hoffman JoAnne (2008) Diasporic Networks, Political Change, and the Growth of Cabo-Zouk Music, in Luís Batalha and Jorgen Carling Eds., Transnational Archipelago. Perspectives on Cape Verdean Migration and Diaspora, Amsterdam, Amsterdam University Press, pp. 205-220.

Hutchinson Sidney (2014) Dancing in Place. An Introduction, in Sidney Hutchinson Ed., Salsa World. A Global Dance in Local Context, Philadelphia, Pennsylvania, Temple University Press, pp. 1-25.

Jiménez Sedano Livia (2020) Kizomba beyond Angolan-ness and Lusofonia:The transnational dancefloor, Atlantic Studies, 17 (1), pp. 91-109.

Jiménez Sedano Livia (2019) "From Angola to the world", from the world to Lisbon and Paris: How structural inequalities shaped the global kizomba dance industry, Poetics, 75, p. 101360.

Kabir Ananya (2018) Afro-Latin-Africa. Movement and Memory in Benin, in May Hawas Ed., The Routledge Companion to World Literature and World History, London, Routledge, pp. 234-245.

Kabir Ananya (2013) The Dancing Couple in the Black Atlantic Space, in Emilia María Durán-Almarza and Esther Álvarez-López Eds., Diasporic Women's Writing of the Black Atlantic, New York, Routledge, pp. 133-150.

Manthei Jennifer J. (2007). The Brazilian Mulata: A Wood for All Works, in Hendrick Kraay Ed., Negotiating Identities in Modern Latin America, Calgary, University of Calgary Press, pp. 189-214.

McMains Juliet (2016) "Hot" Latin Dance: Ethnic Identity and Stereotype, in Anthony Shay and Barbara Sellers-Young Eds., The Oxford Handbook of Dance and Ethnicity, Oxford and New York, Oxford University Press, pp. 480-500.

Moorman Marissa (2008) Intonations. A Social History of Music and Nation in Luanda, Angola, from 1945 to Recent Times, Ohio, Ohio University Press, 289 p.

Pacini-Hernandez Deborah (2014) Urban Bachata and Dominican Racial Identity in New York, Cahiers d'études africaines, 4 (216), pp. 1027-1054. 
Pietrobruno Sheenagh (2006) Salsa and its transnational moves, Oxford, Lexington Books, 254 p.

Soares André Castro (2015) Entre Luanda, Lisboa, Milão, Miami e Cairo. Difusão e Prática da Kizomba, Unedited Master's Thesis, Lisbon, ISCTE-IUL, University Institute of Lisbon.

Tavares Manuel de Jesus (2005) Aspectos evolutivos da música cabo-verdiana, Praia, Instituto Cultural Camões, 180 p.

Thussu Daya Kishan (2007) Mapping media global flow and contra-flow, in Daya Kishan Thussu Ed., Media on the Move. Global flow and contra-flow, London, Routledge, pp. 10-29.

Travassos Elizabeth (2004) Por uma cartografia ampliada das danças de umbigada, in José Machado Pais, Joaquim Pais de Brito and Mário Vieira de Carvalho Coords., Sonoridades luso-afro-brasileiras, Lisboa, Imprensa de Ciências Sociais, pp. 227-253.

Varriale Simone and Lavie Noa (Forthcoming) Introduction. Special Issue on GlobalTastes:TheTransnational Spread of Non-Anglo-American Culture, Poetics.

Waxer Lise (2013) Situating Salsa: Global Markets and Local Meanings in Latin Popular Music, London, Routledge, 476 p.

Wimmer Andreas (2013) Ethnic Boundary Making. Institutions, Power, Networks, Oxford, Oxford University Press, 293 p. 


\section{Livia Jiménez Sedano}

\section{Kizomba Dance: From Market Success to Controversial National Brand}

This paper aims to analyze how the global contra-flow of a dance style kizomba - generated an impact on the symbolic representation of a nation Angola - nd the controversies this national branding involves. The kizomba couple dance style became popular in some Portuguese-speaking African cities and nightclubs in Lisbon in the 1980s. In the mid-1990s, the style underwent commodification in Portugal. In less than ten years, it went onto become a global dance industry in which teachers compete to attract students and correspondingly triggering heated debates on the Angolan-ness, Cape-Verdean-ness, African-ness or the global character of kizomba to legitimize their own practices. In this context, the Angolan state has also capitalized on kizomba's global success to claim the music and the dance as national symbols. Our conclusion points to how global industries have gained greater influence over the definition of national symbols in late modernity, a process to which former colonies would seem more vulnerable.

\section{La danse kizomba : du succès commercial à une marque nationale controversée}

L'objectif de cet article est d'analyser comment la globalisation contre-hégémonique d'une danse - la kizomba - a eu une répercussion sur la représentation symbolique d'une nation - l'Angola - et les polémiques suscitées. La danse de couple appelée kizomba est devenue populaire dans certaines villes de l'Afrique lusophone et à Lisbonne pendant les années 1980. Au milieu des années 1990, une version commerciale de la danse est introduite en Portugal et ensuite globalisée. Les professeurs entrent en concurrence pour attirer des élèves, et mènent des débats sur l'angolanité, la cap-verdianité, l'africanité ou le caractère global de la danse pour donner de la légitimité à leurs propres pratiques. L'État d'Angola a ainsi profité du succès de la kizomba pour revendiquer la musique et la danse comme symboles nationaux. En conclusion, les industries globales sont devenues centrales pour définir les symboles nationaux dans le contexte néolibéral, notamment dans le cas des ex-colonies.

\section{La danza kizomba: de éxito de mercado a marca nacional controvertida}

El objetivo de este artículo es analizar cómo la globalización contra-hegemónica de un estilo de baile - la kizomba - ha influido en la representación simbólica de una nación - Angola - y las polémicas circundantes. El baile de pareja llamado kizomba se popularizó en ciertas ciudades y clubes nocturnos del África de lengua portuguesa y de Lisboa durante los 1980. A mediados de los 1990, se creó una versión comercial en Portugal que fue globalizada. En esta industria global, los profesores compiten por atraer alumnos, generando enardecidos debates sobre la angolanidad, caboverdianidad, africanidad o carácter global del baile para legitimar su propia práctica. En este contexto, el estado de Angola también ha aprovechado el éxito de la kizomba para reclamar la música y el baile como símbolos nacionales. En conclusión, las industrias globales han adquirido una enorme relevancia para definir los símbolos nacionales en el capitalismo tardío, especialmente en países que fueron colonizados. 